Contents list available at IJRED website

Int. Journal of Renewable Energy Development (IJRED)

Journal homepage: www.ijred.com

\title{
Implications of Charcoal Briquette Produced by Local Communities on Livelihoods and Environment in Nairobi- Kenya
}

\author{
M. Njenga*ab, A. Yonemitsuc, N. Karanjaa, M. Iiyamab, J. Kithinjia, M. Dubbelingd, C. Sundberge \\ and R. Jamnadass ${ }^{b}$
}

a University of Nairobi, Box 30197-00100 Nairobi, KENYA

${ }^{b}$ World Agroforestry Centre, Box 30677-00100, Nairobi, KENYA

c University of Tsukuba, JAPAN

${ }^{d}$ RUAF-Foundation (International Network of Resource Centres on Urban Agriculture and Food Security),

Kastanjelaan 5, 3833 AN Leusden, the NETHERLANDS

e Swedish University of Agricultural Sciences, Box 7032, 75007 Uppsala, SWEDEN

\section{Article history:}

Received Dec 5, 2012 Received in revised form Jan 18, 2013 Accepted Jan 20, 2013 Available online

\begin{abstract}
The residents of Nairobi, Kenya, use 700 tonnes of charcoal per day, producing about 88 tonnes of charcoal dust that is found in most of the charcoal retailing stalls that is disposed of in water drainage systems or in black garbage heaps. The high costs of cooking fuel results in poor households using unhealthy materials such as plastic waste. Further, poor households are opting to cook foods that take a short time to prepare irrespective of their nutritional value. This article presents experiences with community self-help groups producing charcoal fuel briquettes from charcoal dust in poorer nieghbourhoods of Nairobi for home use and sale. Households that produced charcoal fuel briquettes for own use and those that bought them saved $70 \%$ and $30 \%$ of money spent on cooking energy respectively. The charcoal fuel briquettes have been found to be environmentally beneficial since they produce less smoke and increase total cooking energy by more than $15 \%$, thereby saving an equivalent volume of trees that would be cut down for charcoal. Charcoal briquette production is a viable opportunity for good quality and affordable cooking fuel. Bioenergy and waste management initiatives should promote recovery of organic by-products for charcoal briquette production.
\end{abstract}

Keywords: charcoal, development, community based charcoal briquetting, cooking fuel, poor neighbourhoods

\section{Introduction}

Growing energy demand is one of the major challenges facing the world. In Sub-Saharan Africa (SSA), over $72 \%$ of urban and $98 \%$ of rural households depend on fuelwood for energy (Bailis et al. 2005). Charcoal is the principal fuel that provides energy for $82 \%$ of urban and $34 \%$ of rural households in Kenya (Kalekezi 2002; MoE 2002). Demand for biomass energy for cooking is likely to increase with population growth and an increasing urbanization rate where the latter in Kenya is currently 6.3\%. The annual per capita consumption of charcoal in Kenya is about $150 \mathrm{~kg}$ which translates to an annual national consumption of 2.4 million tonnes (Mutimba \& Barasa 2005) while available biomass energy fall short of meeting demand and the difference has risen from $46 \%$ in 1980 to $57 \%$ in 2000 (Mugo et al. 2007). Dependence on charcoal for cooking is similar in Tanzania, Zambia, and Ethiopia, where $80 \%, 85 \%$, and $70 \%$ of urban households rely on it, respectively (Chidumayo et al. 2002; Yigard 2002; Ngerageza 2003). The poor populations, who are the

\footnotetext{
* Corresponding author:

E-mail: m.njenga@cgiar.org
} 
Citation: Njenga, M., Yonemitsu, A., Karanja, N., liyama, M., Kithinji, J., Dubbeling, M., Sundberge, C. \& Jamnadass, R. (2013) Implications of Charcoal Briquette Produced by Local Communities on Livelihoods and Environment in Nairobi, Kenya. Int. Journal of Renewable Energy Development 2(1), 19-29

$P$ a g e $\mid \mathbf{2 0}$

majority users of wood charcoal, cannot afford to use electricity and/or liquid petroleum gas (LPG) for cooking because of the high costs of fuel and related cooking appliances (Mugo et al. 2007). Combustion of bio-fuels emits pollutants that contribute to over 1.6 million annual deaths globally, of which 400000 occur in sub-Saharan Africa (SSA) (Bailis 2005). There is a need therefore to link knowledge on charcoal briquette quality to indoor air pollution.

Kituyi (2004) describes this challenge facing poor households in accessing cooking energy as being shared by nations in SSA and he further argues that for the short and medium terms, any sustainable development solutions in the household energy sub-sector in Africa must necessarily focus on biomass energy technology development and dissemination. Due to the high costs of cooking fuel, poor households often use unhealthy materials such as old shoes, used plastic containers and old plastic basins (Gathui \& Ngugi 2010). Further poor households are opting to cook foods that take a short time to prepare irrespective of their nutritional value. For sustainable development and green economy to be achieved new and renewable energy sources, greater reliance on advanced energy technologies and sustainable use of traditional energy sources have been identified as key areas for global dialogue (UNEP 2011).

Faced with poverty and unemployment, communities are turning to charcoal briquette making through recovering charcoal dust, among other organic by-products. There is a loss of about $10-15 \%$ along the charcoal supply chain in form of dust or fines as a result of breakages during handling and this dust is mainly found at the retailing and whole sale stalls. Charcoal dust poses disposal challenges. Most often, it is either dumped in open drainage systems or left as unattended heaps that risk environmental pollution. Biomass residues generated by wood-based industries in most developing countries have potential to supplement energy sources such as firewood, in domestic energy needs (Suarez et al. 2000). However, only a small proportion of the residues are used as fuel because of their high moisture content, low energy density and transportation costs (Nasrin et al. 2008). Densification of biomass residues into fuel briquettes presents an opportunity to reduce these drawbacks. Fuel briquettes are made by compressing biomass material such as charcoal dust, sawdust and other wood residues or agricultural by-products into a uniform solid unit (Sotannde et al. 2010a; Rousseta et al. 2011). Briquetting biomass is done using various techniques, either with or without binder. For charcoal and other biomass material that lacks plasticity, addition of a sticking or agglomerating material, preferably combustible is required to enable the formation of solid fuel briquettes (Rousseta et al. 2011). Common binders are starch, gum arabica, soil, animal dung or waste paper. Biomass briquettes in the developing countries are mainly for domestic usage (Sotannde et al. 2010b).
Biomass residues generated by the wood-based industry in most developing countries have potential to alleviate cooking energy poverty as demonstrated in Cuba, Nigeria, Brazil, China, and Kenya (Wamukonya \& Jenkins 1995; Suarez et al. 2000; Sotannde et al. 2010a; Rousseta et al. 2011; Gominho et al. 2012). Agricultural by-products are used in briquette production such as rice straw and rice bran in China (Chou et al. 2009), maize cobs in Thailand (Wilaipon 2007) and coffee husks in Brazil (Felfli et al. 2010). Adoption of fuel briquette is spreading in Kenya's urban and rural areas and the type of fuel briquettes produced depends on the locally available material. A study by Terra Nuova and Amref Kenya showed that sugar bagasse was used in Mumias, charcoal dust was used in Nairobi, coffee husks were used in Kiambu/Muranga, gum arabica was used in Isiolo, tree leaves were used in Machakos/Makueni, water hyacinth was used in Kisumu and rice husks were used in Mwea (Terra Nuova \& Amref-Kenya 2007).

To provide cooking energy from a range of sources to meet people's needs will require adequate, reliable and affordable supplies, that result in minimal impact on the environment (Olz 2007). In Kenya, production of fuel briquettes aims at supplying affordable, good quality cooking fuel, creating employment and income generation. To that end, fifty percent of briquettemaking enterprises in the country are communitybased organizations comprising of women and youth (Terra Nuova \& Amref-Kenya 2007). Others involved in briquette production include non-governmental organizations and private companies. Most fuel briquette-making initiatives in Kenya are located in urban and peri-urban areas, with Nairobi hosting over half of them. The main raw material used in fuel briquette production by these urban based enterprises, is charcoal dust, which is bound with either biodegradable paper or soil. Charcoal dust as a main raw material in briquette production is popular in urban areas which could be associated to the high availability of charcoal dust following high use of charcoal among the poor and low income households. The other reason is that out of their trial on error practices, communities have found charcoal dust to yield a high quality product compared to other raw materials that they have tried to use such as maize comb and bean husks. And finally customers are more familiar with charcoal fuel briquettes which looks and burns like wood charcoal. However due to challenges of accessing cooking fuel in rural areas other raw materials such as rice husks, rice straw, household organic waste are gaining popularity too.

The aim of this paper is to discuss the potential of charcoal briquette as an alternative cooking fuel based on research work carried out in Nairobi, Kenya. Charcoal briquette is a type of fuel briquette that is made from charcoal dust bonded with either paper or soil. It is the most commonly produced and used type of fuel briquette. The paper focuses on four aspects 
important for the utilization and sustainability of urban charcoal briquette production in developing countries. These aspects are (i) charcoal briquette production methods adopted by community-based groups (ii) benefits for poverty alleviation, food security and the environment, (iii) charcoal briquette quality and (iv) policy issues.

\section{Methodology}

\subsection{Study site}

The study was conducted in Nairobi, Kenya, which is located in southern Kenya on $1^{\circ} 00^{\prime \prime} \mathrm{N}$ and $30^{\circ} 00^{\prime \prime} \mathrm{E}$ at an elevation of $1670 \mathrm{~m}$ above sea level and covers an area of 700 square kilometres. The city's population is estimated at three million with an annual growth rate of 2.8\% between 2000-2015 and constitutes $7.5 \%$ of the country's population. Seventy five percent of the urban population growth is absorbed by informal settlements. Nairobi employs $25 \%$ of Kenyans and $43 \%$ of the country's urban workers. Sixty per cent of the city's population lives in low-income informal settlements and the numbers of urban poor projected to increase to 65 percent by 2015. (UN-Habitat 2006). The city generates 2000 tonnes of waste, only $40 \%$ of which is collected and disposed properly (ITDG-EA 2003). Seventy percent of the waste is biodegradable. (JICA 1997). Kibera is located within the legal city boundaries of Nairobi, approximately seven kilometer southwest of the city center. It is one of the most densely populated informal settlements in the world, and Africa's largest slum. It is not clear as to how many people live in this slum as the census of 1999 had the figure at close to one million while the 2009 census stands at 0.4 million within 2.5 square kilometers.

\subsection{Surveys on production methods and use of fuel briquettes by local communities}

Firstly a survey was conducted among seven community self-help groups (SHGs) in 2010. These charcoal briquette producing community SHG's comprised all those identified and located using an existing database on self-help groups involved in waste management in Nairobi (Njenga et al. 2010). A semistructured questionnaire was administered to members of the groups through focus group discussions. These discussions were to document types, amounts and sources of raw materials and binders and production methods used in briquette making. Detailed procedures on fuel briquette production processes in Nairobi can be found in Njenga et al. in press. Secondly a survey was conducted among 199 households on use of charcoal briquettes. Fifty households were selected along four footpaths within a 250-metre radius of a charcoal briquette production site at Gatwekera village in the
Kibera slums, in which every fifth household on those paths was interviewed.

\subsection{Characterization of calorific value of charcoal fuel briquettes}

Charcoal fuel briquettes were obtained during the focus group discussions (FGD) from seven of the eight identified community groups as one group did not have any samples at the time of the survey. Forty charcoal fuel briquettes were randomly sampled from the pieces ready for sale from each group to determine relative proportion of charcoal dust (CD) to binding agents (\%). The six types of fuel briquettes collected include CD+Paper1 (3\% wt), CD+Paper2 (7\% wt), CD+Paper3 (26\% wt), CD+Carton (46\% wt), CD+Soil1 (20\% wt), CD+Soil2 (34\% wt). Each type of briquette listed originated from only one community SHG.

Charcoal fuel briquettes samples were analysed using Infrared (IR) Spectroscopy following procedures described by Shepherd and Walsh (2007). In Nearinfrared (NIR) and Mid-infrared (Mid-IR) the MPA Multi Purpose FT-NIR Analyzer and Tensor 27-HTSXTBruker FTIR equipments were used respectively. A double sampling approach was used whereby a spectral library of the total 320 samples was first established and then a representative subset of 42 samples was selected based on the chemical and physical spectral diversity in the library (Shepherd \& Walsh 2007). These 42 samples were analysed for calorific value following procedures described by Findlay (1963). Calorific value is the heat released during combustion per mass unit of fuel (Vvan Loo \& Koppejan 2009). As described by Shepherd and Walsh (2007) calibration based on the 42 samples were used to predict calorific value for the entire 320-sample spectral library.

\subsection{Cooking tests}

Cooking tests were carried out at the Human Needs Project (HNP) ground at Kibera slum in early 2012 to measure the amount of fuel and length of time taken to cook a meal for a standard household of five people. Six hundred and eighty grams of CD+Paper with 13\% proportion of binder, 850 grams of CD+Soil with $20 \%$ proportion of binder, 890 grams of wood charcoal and 357 millitres of kerosene were used to cook a traditional meal. The traditional meal cooked is commonly known as Githeri which is a mixture of 500 grams of green maize (Zea mays) and 500 grams of dry common bean (Phaseolus vulgaris).

\subsection{Data management and analysis}

Data was analysed using Microsoft Excel software for descriptive statistics such as mean and standard error. Microsoft Excel was also used to elicit the bar graphs and the box plot. 
Citation: Njenga, M., Yonemitsu, A., Karanja, N., liyama, M., Kithinji, J., Dubbeling, M., Sundberge, C. \& Jamnadass, R. (2013) Implications of Charcoal Briquette Produced by Local Communities on Livelihoods and Environment in Nairobi, Kenya. Int. Journal of Renewable Energy Development 2(1), 19-29 P a g e $\mathbf{2 2}$

\section{Result And Discussion}

\subsection{Community groups and briquette production methods}

\subsubsection{Community groups and member profile involved in charcoal briquette production}

The survey among the SHGs revealed that the groups members came from the low income, high density neighbourhoods experiencing high unemployment and poverty. These are the neighbourhoods where charcoal consumption is high given that most households can seldom afford other types of cooking fuel such as LPG and kerosene. These neighbourhoods provide good market opportunities for the sale and use of charcoal fuel briquettes which compliment charcoal as these two types of fuel use similar cook stoves.

The charcoal briquette-making groups comprised of 68 female and 101 male with $78 \%$ of the members being youth below 35 years of age (F-45:M-89). The high level of youth involvement in charcoal briquette enterprises is one form of creating green jobs contributing towards sustainable cities. It helps address unemployment in Kenyan urban areas that is estimated at 18\%, (F-24\%:M-14\%) (MoPND, 2003).

of the survey respondents, $39 \%$ had a primary education (F-50\%: M-50\%), 46\% had a secondary education (F-35\%:M-65\%) and 15\% had some tertiary education (F-28\%: M-72\%) an indication of high literacy level in the enterprise (Table 1). There were many females with primary education but very few of them had above secondary school education and hence trainings should be designed in a away that they suit their level of education.

of the community group members, $87 \%$ were directly involved in charcoal briquette production activities while the rest were students $(3 \%)$ or involved in other group activities such as garbage collection (6\%) and compost production (1\%) and a few operated their own small bunisesses $(2 \%)$ or were in formal employment (2\%). The group members directly involved in charcoal briquette production allocated less than $30 \%$ of their time to this activity and this time was mainly during their free time. These group members were also involved in other income generating activities such as other small businesses, rural and urban agriculture, casual labour and formal employment, in that order. The SHG produced between 5,760 and 336,000 pieces of charcoal fuel briquettes per year as shown in Table 2.

SHGs play a great role in addressing cooking-energy poverty where they comprise $50 \%$ of fuel briquetting enterprises (Terra Nuova \& AMREF-Kenya 2007). The SHGs come together to generate income, create employment opportunities, and source cooking energy.
Further, they also clean their neighbourhoods that are faced with waste management challenges as only $40 \%$ of waste generated in the city is collected and disposed of. Fuel briquetting contributes to the informal economy which is known to involve people in the slum more than non-slum dwellers (UN-Habitat 2010). The SHG's have been producing charcoal briquette since the early 90's which was noted among two of them while the rest five started the enterprise in the early 2000. A study on groups involved in organic waste management in Nairobi showed similar objectives of members of the community coming together in poor neighbourhoods to address their livelihood and environmental challenges (Njenga et al. 2010).

\subsubsection{Charcoal briquette production methods adopted by the community groups}

The study among SHG's involved in fuel briquette production established that charcoal dust bonded with paper, or soil were the main raw materials used in briquette production in Nairobi. The main sources of charcoal dust was charcoal retailing stalls for six groups, while one group sourced it from dumping sites. The groups that sourced charcoal dust from charcoal retailing stalls bought it at US\$0.02 per kilogram. Waste paper was sourced from either newspaper vendors, schools or dumping sites. The group that collected paper from dumpsites and those that obtained paper from schools got it for free. Only one group sourced paper from newspaper vendors and bought at US\$0.4 per kilogram. Soil was collected for free from river banks or road reserves. And water was purchased for US $\$ 0.02$ per litre from water vendors or kiosks or sourced from shallow wells.

The organic biomass and binders were hand sorted to remove impurities such as pieces of wood, metal and plastics. Charcoal dust was sieved through recycled nylon $5 \mathrm{~mm}$ nets to separate the fine dust from bigger particles which were later mixed at a ratio of 1:1. Paper was shredded manually then soaked in water for about 2-3 hours before mixing with charcoal dust. To test for consitency and stability of the mixture, the slurry was squeezed in one hand and then held between the thump and the index finger and if it fell apart, binder was added until it held together. The mixed slurry was pressed to compact it into solid blocks of different shapes and sizes and squeeze out the water using methods shown in Fig. 1.

Charcoal fuel briquettes were dried either in the sun or under shade. During the dry season they took about eight days to dry while during the wet season they took 11 days. The production methods applied by the groups indicate a large potential of its application in different regions where the raw materials depend on locally 
Table 1

Education level and gender composition of group members producing charcoal briquettes

\begin{tabular}{|c|c|c|c|c|c|c|c|c|c|c|c|}
\hline \multirow{2}{*}{$\begin{array}{l}\text { Community groups } \\
\text { Gender of members }\end{array}$} & \multicolumn{2}{|c|}{$\begin{array}{l}\text { No formal } \\
\text { education }\end{array}$} & \multicolumn{2}{|c|}{ Primary } & \multicolumn{2}{|c|}{ Secondary } & \multicolumn{2}{|c|}{ College } & \multicolumn{2}{|c|}{ University } & \multirow[t]{2}{*}{ Total } \\
\hline & M & $\mathrm{F}$ & M & F & M & $\mathrm{F}$ & M & $\mathrm{F}$ & M & $\mathrm{F}$ & \\
\hline Nyooni self-help group & & & & & 11 & & & & & & 11 \\
\hline Soweto youth in action & & & 2 & 1 & 7 & 2 & 7 & 2 & & & 21 \\
\hline Vijana youth cleaners & & & 1 & & 6 & & 7 & 2 & & 1 & 17 \\
\hline City garbage recyclers & & & & 1 & 5 & & & & & & 6 \\
\hline $\begin{array}{l}\text { Kayole environmental } \\
\text { management association }\end{array}$ & & & 30 & 5 & 21 & 23 & 3 & 2 & 1 & & 85 \\
\hline Tujikaze women group & & 1 & & 26 & & 1 & & & & & 28 \\
\hline $\begin{array}{l}\text { New beginning sympathy women } \\
\text { group }\end{array}$ & & & & & & 1 & & & & & $\underline{1}$ \\
\hline Total & & 1 & 33 & 33 & 50 & 27 & 17 & 6 & 1 & 1 & 169 \\
\hline
\end{tabular}

Table 2

Annual charcoal briquette production capacity by the SHG'S

\begin{tabular}{|c|c|c|c|c|c|}
\hline Community groups & $\begin{array}{l}\text { Pieces } \\
\text { produced } \\
\text { per day }\end{array}$ & $\begin{array}{l}\text { Number of days } \\
\text { worked in a } \\
\text { month }\end{array}$ & $\begin{array}{l}\text { Pieces } \\
\text { produced per } \\
\text { year }\end{array}$ & $\begin{array}{l}\text { Weight per } \\
\text { piece (grams) }\end{array}$ & $\begin{array}{l}\text { Total production } \\
\text { per year } \\
\text { (kilograms) }\end{array}$ \\
\hline Nyooni self-help group & 450 & 12 & 64800 & 280 & 18144 \\
\hline Soweto youth in action & 600 & 12 & 57000 & 230 & 13110 \\
\hline Vijana youth cleaners & 100 & 12 & 14400 & 250 & 3600 \\
\hline City garbage recyclers & 60 & 8 & 5760 & 430 & 2477 \\
\hline $\begin{array}{l}\text { Kayole environmental } \\
\text { management association }\end{array}$ & 12000 & 20 & 288000 & 330 & 95040 \\
\hline Tujikaze women group & 5600 & 5 & 336000 & 920 & 309120 \\
\hline New beginning sympathy women group & $\underline{250}$ & $\underline{8}$ & $\underline{24000}$ & $\underline{100}$ & $\underline{2400}$ \\
\hline
\end{tabular}

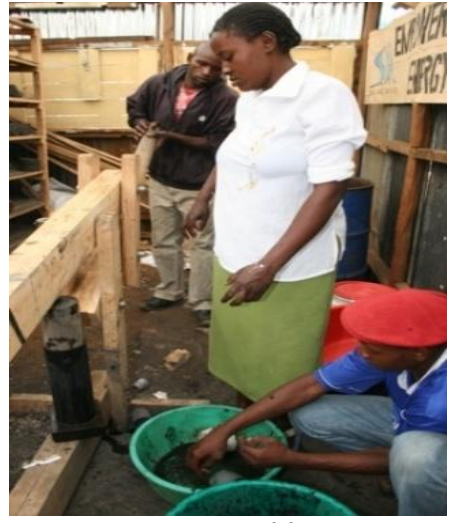

(a)

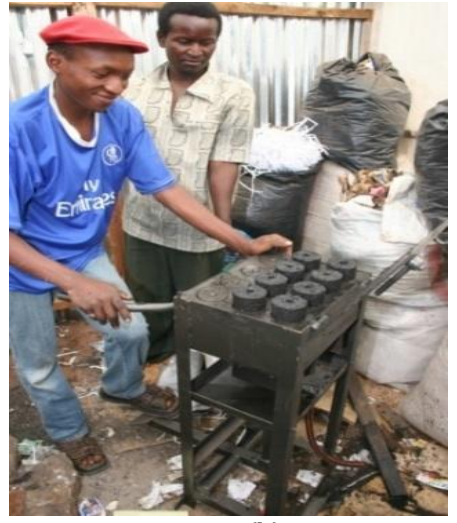

(b)

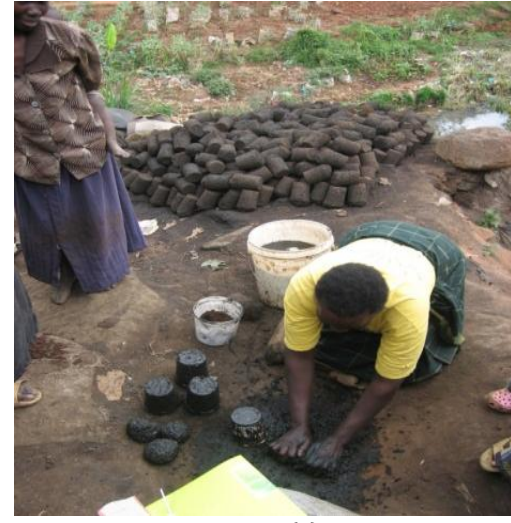

(c)

Fig. 1 (a) Wooden manual, (b) Metal manual press, (c ) Molding in recycled plastic container containers

available biomass material. For instance rice husk is bonded with rice bran and maize cob is bonded with molasses in China and Thailand respectively (Wilaipon 2007; Chou 2009).

\subsection{Socio-economic aspects and adequacy of fuel briquettes as fuel}

\subsubsection{Income and factors influencing use of charcoal briquettes}

Monthly incomes from sales of charcoal fuel briquettes by the community groups varied between US\$7-\$1771 during the dry seasons and US\$7-\$2240 during the wet seasons. Charcoal fuel briquettes were traded in pieces of between 100 to 920 grams each and the prices were different among the groups. Tujikaze women group from Kibera had the lowest price but realised the highest income due to high volumes traded. The main customers include households, food kiosks, institutions such as schools and chicken hatcheries. As illustrated in Fig. 2a, 70\% of the 199 interviewed households living within $250 \mathrm{~m}$ radius of a briquette production site in Kibera used charcoal fuel briquettes. Most of those who produced and used charcoal fuel briquettes were from the very poor households in the low income bracket with annual earnings ranging from USD128 to 960 per year. There were more producers who made charcoal fuel briquettes for both home use and sale than those who produced for home use only implying that this activity is both for sustenance and commercial. 
Citation: Njenga, M., Yonemitsu, A., Karanja, N., liyama, M., Kithinji, J., Dubbeling, M., Sundberge, C. \& Jamnadass, R. (2013) Implications of Charcoal Briquette Produced by Local Communities on Livelihoods and Environment in Nairobi, Kenya. Int. Journal of Renewable Energy Development 2(1), 19-29

$\mathrm{P}$ a g e $\mid \mathbf{2 4}$

Households that produced fuel briquettes for home use made savings of over $70 \%$ while for those who purchased saved $30 \%$. The highest savings was $82 \%$ noted among the low income households that produced charcoal fuel briquettes as they spent US $\$ 40$ per year on cooking fuel compared to US\$223, spent by their counterpart households that did not use charcoal fuel briquettes. The high level of saving by these low income households is due to charcoal briquette production being cheaper than buying fuel briquettes while further savings are generated by the non-use of kerosene. The income that women generated through selling fuel briquettes or saved through use of fuel briquettes was spent on other livelihood needs such as food, health, school fees and paying rent. The household survey in Kibera revealed that briquette producers were all women majority of who did not belong to Tujikaza women group that was involved in the focus group discussions. This indicative the role they often play in sourcing cooking energy. Dependence on wood charcoal was highest among the poorest households who have the most limited resources that could be used to procure other types of cooking energy like kerosene.

The study involved households within 250-metres radius from the charcoal briquette production site and hence the high use of charcoal fuel briquettes in the studied village may have been influenced by the nearness to the source resulting into high awareness of the product. Other factors that may have contributed to use of charcoal fuel briquettes include family size where for instance charcoal briquette producing households had more people (Table 3). The increased need of poorer households to live within tight financial budgets is accomplished through production and use of charcoal fuel briquettes, as opposed to consuming other fuels. More female-headed households produced charcoal briquette for home use hence contribution of gender in adoption of this alternative fuel. On the other hand education level of household head also contributed to involvement in production of charcoal fuel briquettes which could be associated to higher awareness and ability to gather information on one's own benefit. Education was found to play a role in adoption of improved farming technologies in Nigeria as found by Odoemenen and Obinne (2010).

Charcoal fuel briquettes have various characteristics that contribute to their preference for household cooking. All the 140 households that used charcoal fuel briquettes in Kibera preferred them to charcoal due to their lower price. Nearly unanimously, 98\% of households stated that charcoal fuel briquettes burn for a longer period of time than charcoal. This time advantage makes fuel briquettes suitable for preparing foods that require a longer time to cook such as dry grains, foods which many households are currently abandoning due to the high costs of other fuels (Fig. 3).

Production of less smoke by charcoal fuel briquettes was one of the characteristics that contribute to their preference. Observations during the cooking tests showed that charcoal fuel briquettes forms no soot on pots after cooking hence user friendly to a community with limited access to clean water and living space. The observations by the users were confirmed by analyses showing that these fuel briquettes gave lower indoor air emissions of carbon monoxide (CO) and fine particulate matter $\left(\mathrm{PM}_{2.5}\right)$ compared to charcoal, when used in cooking stoves (Njenga et al. in press). The same analysis showed that charcoal fuel briquettes had lower emissions of $\mathrm{CO}$ and $\mathrm{PM}_{2.5}$ than fuel briquettes made from sawdust bonded with gum arabica resin (Njenga et al. in press).

\subsubsection{Charcoal briquettes contribution to food security and saving of trees}

Cooking-energy poverty is one of the main challenges faced by poor households in their efforts to feed their families. Charcoal briquettes, in addition to being cheap and available within the neighbourhoods, can also contribute to food security. This possible security is evidenced by cooking tests that showed that, the 88 tonnes of charcoal dust produced in Nairobi daily could be used instead to produce CD+Soil (20\% binder) fuel briquettes that could cook 129,000 traditional meals of a mixture of green maize (Zea mays) and dry common bean (Phaseolus vulgaris) commonly known as Githeri. Consequently, in a year, charcoal briquettes could result in cooking about 45 million meals from recovering the charcoal dust produced in the city. The cooking tests showed that each meal takes 178 minutes, 168 minutes and 166 minutes to cook with charcoal briquette, charcoal and kerosene respectively. This projection assumes a Kenyan standard household of five people.

Cooking the meal with charcoal briquettes costs 3 ksh (US\$0.04 - 850 grams) with charcoal costs $26 \mathrm{ksh}$ (US\$0.35 - 890grams of charcoal) and with kerosene, 45 ksh (US\$0.6 - 0.36 litres of kerosene). Cooking the meal with charcoal briquettes thus costs $88 \%$ and $93 \%$ less than cooking the meal with charcoal and kerosene respectively. This would benefit poor households who comprise $60 \%$ of the city's population. Recovering the dust that would otherwise get burned could result in the production an extra over 15\% cooking energy hence saving similar amount of trees that would be cut for charcoal (Njenga et al. unpublished data). These findings are timely as there is an expected increase in bioenergy use that calls for identification of conditions under which bioenergy systems can be implemented sustainably (Hecht et al. 2009). Sustainability of bioenergy should be addressed both at large regions and local sites and should apply to diverse stakeholders (McBride et al. 2011). In this case community groups are playing a pivotal role in the development of cooking energy that supports environmental sustainability. 
Table 3

Characteristics of interviewed household in Kibera slum

\begin{tabular}{|c|c|c|c|c|c|c|c|c|c|c|c|c|c|}
\hline & \multicolumn{4}{|c|}{ Producer } & \multicolumn{4}{|c|}{ Buyer } & \multicolumn{4}{|c|}{ Non-user } & \multirow{2}{*}{$\begin{array}{c}\text { Total } \\
\text { Avg }\end{array}$} \\
\hline & $\mathbf{L}$ & $\mathbf{M}$ & H & Avg & $\mathbf{L}$ & $\mathbf{M}$ & H & Avg & $\mathbf{L}$ & $\mathbf{M}$ & H & Avg & \\
\hline $\mathbf{N}$ & 12 & 10 & 9 & & 37 & 35 & 37 & & 15 & 21 & 23 & & \\
\hline HH size (persons) & 6.8 & 5.9 & 7.3 & 6.7 & 5.3 & 5.6 & 5.4 & 5.4 & 5.5 & 4.1 & 4.5 & 4.7 & 5.4 \\
\hline Age of $\mathrm{HHH}$ & 38.4 & 34.3 & 36.9 & 36.5 & 32.2 & 33.3 & 34.8 & 33.4 & 32.2 & 30.5 & 32.6 & 31.8 & 33.4 \\
\hline Female headed HH (\%) & 25 & 20 & 22 & 22 & 22 & 11 & 8 & 14 & 33 & 5 & 13 & 17 & 16 \\
\hline $\begin{array}{l}\text { HHH completed secondary } \\
\text { school }(\%)\end{array}$ & 42 & 20 & 22 & 28 & 27 & 17 & 24 & 23 & 13 & 29 & 26 & 23 & 24 \\
\hline Annual income (US\$) & 516 & 1296 & 2808 & 1540 & 566 & 1400 & 2733 & 1566 & 539 & 1336 & 2698 & 1524 & 1576 \\
\hline
\end{tabular}

$\mathrm{N}=$ number of households, $\mathrm{HH}=$ Household, $\mathrm{HHH}=$ Household head, L=low, M=middle, H=High, Avg=Average, Exchange rate US $\$ 1=$ Ksh75

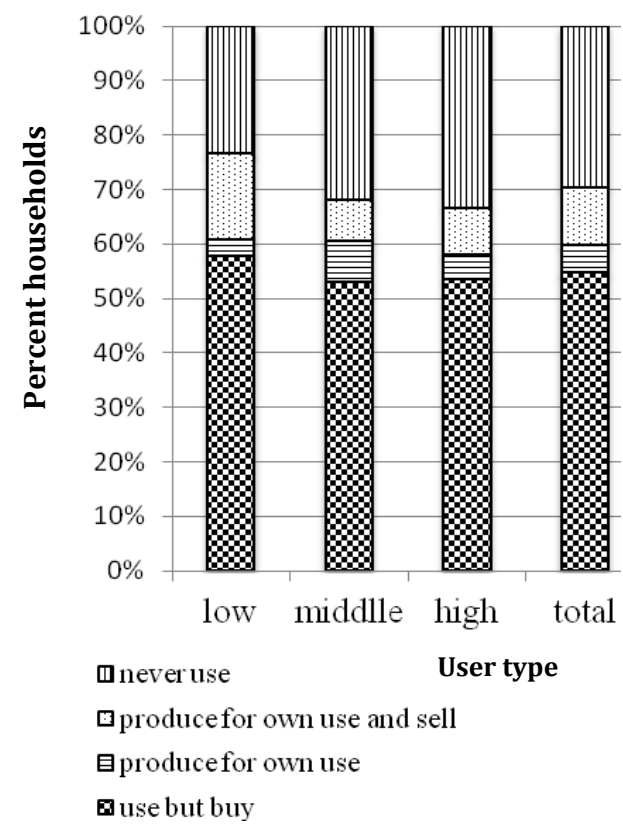

(a)

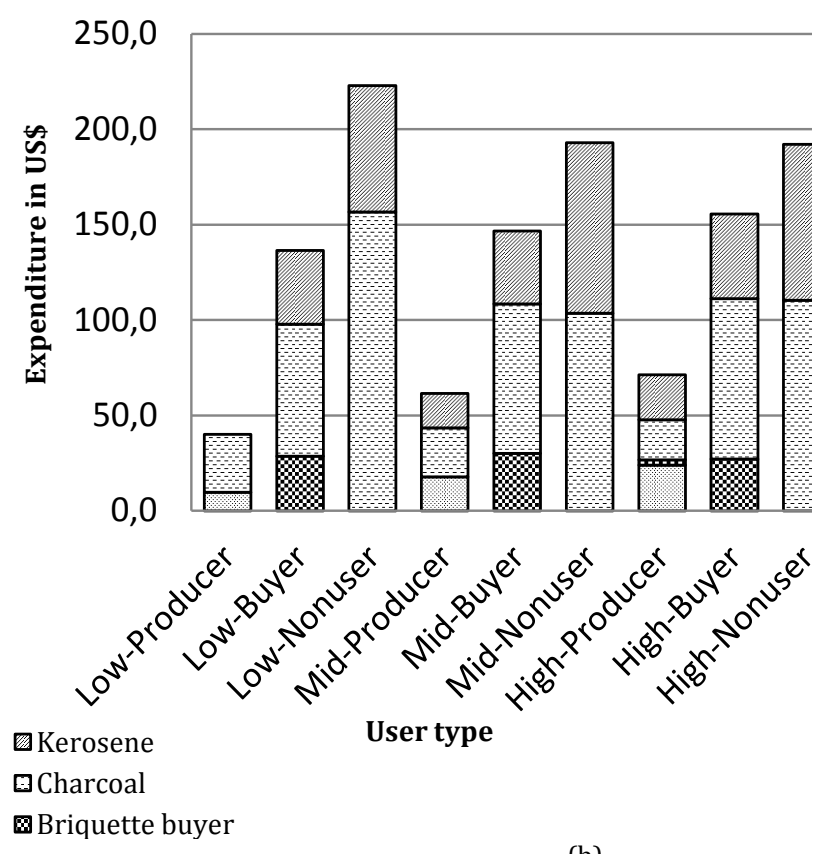

(b)

Fig. 2 Utilization of charcoal briquettes (a) and annual expenses on cooking fuel (b) by the residents of Kibera slums ordered by the different income groups. Low=low income (US\$128-960), mid=middle income (US\$961-1921), high = high income (US\$1921-7200). Producer and buyer used charcoal briquettes; nonuser did not use charcoal briquettes.

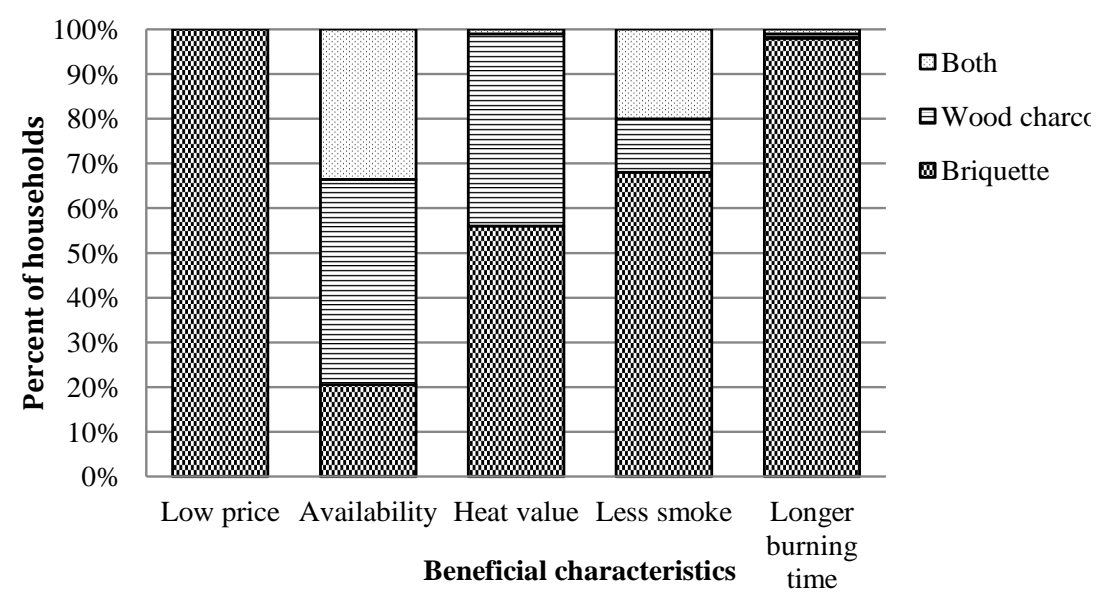

Fig. 3 Consumer preferences of charcoal briquettes compared to wood charcoal 
Citation: Njenga, M., Yonemitsu, A., Karanja, N., liyama, M., Kithinji, J., Dubbeling, M., Sundberge, C. \& Jamnadass, R. (2013) Implications of Charcoal Briquette Produced by Local Communities on Livelihoods and Environment in Nairobi, Kenya. Int. Journal of Renewable Energy Development 2(1), 19-29

$\mathrm{P}$ a g e $\mid \mathbf{2 6}$

\subsection{Charcoal briquette quality}

\subsubsection{Calorific value}

Calorific value of the SHGs briquettes ranged between $13.5 \mathrm{~kJ} / \mathrm{g}$ and $21.4 \mathrm{~kJ} / \mathrm{g}$ (Fig. 3). The highest calorific value was recorded in CD+Paper3 while the lowest was in $\mathrm{CD}+$ Soil2 (Fig.4). While paper as a binder elevated the calorific value of the briquettes, soil had a negative influence. The negative influnce of soil on calorific value is because soil is non-combustible (van Loo \& Koppejan 2009). Results of this study agrees with results in previous studies that showed type of raw materials and proportions used influnce calorific value (Chou et al. 2009). As such there is need for further research to develop standards and guidelines for fuel briquette quality control

Briquettes are a good source of cooking fuel and compare well with the conventional wood charcoal with a $25.3 \mathrm{~kJ} / \mathrm{g}$ calorific value and firewood $13.7 \mathrm{~kJ} / \mathrm{g}$ (Fuwape 1983). Charcoal briquettes in our study had calorific values exceeding $14.1 \mathrm{~kJ} / \mathrm{g}$, which was obtained in maize cob briquettes. in Thailand (Wilaipon 2007). Charcoal briquettes had higher calorific value than that made from sawdust bonded with gum Arabica except where soil was used as a binder (Njenga et al. in press). Charcoal briquettes had higher calorific value than that made from sawdust bonded with gum Arabica except where soil was used as a binder (Njenga et al. in press). Results presented in the box plot in Fig. 3 indicate that the production methods applied to produce CD+Paper1, CD + Carton and CD + Paper3 yielded a product with consistence in calorific value among the analysed samples. The other groups produced a product that had large variation in calorific value among the analysed samples. This information shows the need for technical capacity building of SHGs so that they can produce a product whose quality is known and consistent.

\subsection{Policy relevance of charcoal briquette}

Charcoal briquette production and marketing provide a strategy that contributes to a supply of an affordable source of cooking energy for the poor with the further benefits of contributing to poverty alleviation, food security and environmental management. The enterprise generates income through sales mainly for youth and women involved in production. Charcoal briquette production is carried out by poor communities who have a comparative advantage in local markets as they are located in informal settlements, and consequently benefit from local supply and distribution. The prospects for charcoal briquettes in Kenya is high due to the increasing costs in cooking fuel such as kerosene, liquid petroleum gas and charcoal coupled with increasing rates of urbanization, poverty, food and nutrition insecurity and poor waste management services. The motivation of self-help groups to produce more charcoal briquette depends on the demand from customers and as demand is rising which consequently will mean more income these activity is likely to grow. This activity integrates well with other household chores which most SHG members carry out during their free time and is spreading fast in both urban and rural areas. Various options are discussed below on how to raise the capacity of the SHG's in sustainable charcoal briquette production.

Briquette production improves access of the urban poor to cheap, clean cooking energy that contributes to saving income that is made available for other uses such as food, health and education. Use of charcoal briquettes leaves no soot on cooking pots, reducing consumption of household water for cleaning, as water is a resource that is expensive, insufficient and obtained with a lot of effort in poor neighbourhoods. This water savings is in line with lower water consumption as an indicator of sustainability of biomass energy (McBride et al. 2011).

Unfortunately, slum areas remain generally ignored when it comes to policy interventions, job creation and gender support (UN-Habitat 2010). For these SHGs to prosper and make full impact, local authorities need to provide assistance to these kinds of small enterprises, enabling them to better access resources such as space under lease agreement. This assistance will encourage communities to construct appropriate infrastructure such as beds for drying and selling, as well as stores. Water also needs to be provided at a reasonable cost to these communities. This water access must be aligned to urban planning so as to recognize charcoal briquette production as a productive sector. Although provision of these production services might cause an extra cost in the charcoal briquette enterprises it would help expose briquette producers to potential buyers.

Fuel briquette production needs to also be linked to waste management in which the local authorities can help link the local fuel briquette-producing communities to government institutions, such as schools, for sourcing of paper. In waste management aiming at decentralised reuse and recycling of waste, charcoal briquette making would be a way to reduce the need for transporting waste out of residential areas, by separating and reusing waste close to the source. Waste management stakeholders should facilitate the development of partnerships between local charcoal traders and charcoal briquette producers so that the latter can directly source charcoal dust from the former as opposed to sourcing from dumpsites which has been noted to cause heavy metal contamination (Njenga et al. in press). The $10-15 \%$ waste generated along charcoal supply chain in our urban areas can ensure continued charcoal briquette production if the above concerns are addressed. This trend will follow the foreseen dependence of charcoal use in African cities though sustainable tree production is needed as discussed later in this section. However given the benefits of charcoal 
briquettes as a cheap and environmental friendly cooking energy option, chances are that communities might shift to grinding charcoal for charcoal briquette production and as such there is need for further studies to evaluate the financial and environmental implications of such an undertaking. On the other hand to meet the increasing demand for charcoal briquette there is need to evaluate potential in using other raw materials such as carbonizing the over 230,000 tonnes of sawdust generated annually by Kenya's sawmill industry adding to the unknown amount of existing sawdust mountains across the country, most of which is burned at the site. Carbonizing sawdust before making fuel briquettes is crucial as Njenga et al. (in press) showed risks of high fine particulate matter from burning fuel briquettes made from fresh sawdust.

Briquette can play a role in the social inclusion of unemployed youth and women by providing them an opportunity to raise their income, participate in the cleaning of urban neighbourhoods and the conservation of tree and forest cover. Women bear the load of bringing food to the table for SSA families and it is frustrating if they have food but it cannot be cooked due to lack of fuel.

The Ministry of Energy has mandate to provide adequate energy sources in Kenya. Environmental Management and Coordination Act 1999, paragraph 49, specifies that the Act promotes use of renewable energy sources and charcoal briquettes are one such source. The growing attention by the government on biomass energy is stipulated in The Sessional Paper No. 4. of 2009 on Energy in section 2.4.7 which outlines the importance of recycling municipal and industrial waste for energy. Section 6.3.1 emphasizes the government's support of use and development of efficient cook stoves that if adopted, will elevate the benefits of charcoal briquette burning slowly with less smoke. The paper also supports research and development on alternative sources of energy as well as improvement on efficiency. There is need for implementation of the above policy statements so that briquette technology can be developed in the country.

Development of social - economic - environmental friendly cooking-fuel policies in the country should integrate fuel briquetting as a viable option. There is progress in this aspect as the proposed national biofuel policy in the section on biomass technology, promotes the use of crop and wood residues for energy (MoE, 2009). Community-based self- help groups need to be involved in the government planning process for cooking energy.

Various organizations have been involved in fuel briquette production such as the sugar factories, the Coffee Planters Cooperative Union (KPCU) through recycling their agricultural residues. Chardust Ltd produces charcoal briquettes from charcoal dust sourced from slums of Nairobi. Faced with growing cooking energy needs, fuel briquettes research and development focus are receiving increased recognition by organization such as the Kenya Forest Research Institution (KEFRI), Kenya Industrial Research and Development Institute, Universities, International Research Centres, Development Practitioners and donors. Collaboration would be beneficial amongst stakeholders to share lessons and scale out 'best practices' as well as assisting community groups with technical skills. One way to achieve the collaboration for scaling-out fuel briquette production would be to use the existing institutional relationships organized by the Ministry of Energy that has 10 energy centers located in different parts of the country. Another channel would be through bringing together several SHGs for participatory training. For training to be effective, there is the need for stakeholders to collaborate in development of user guidelines and delivery of the participatory training. The training should be gender responsive both in content and modes of delivery.

Technical capacity-building is needed among charcoal briquette producers to enable production of a quality product which is consistent enough to effectively compete with conventional charcoal. Government and other organizations need to increase financial and other types of support for research on and development of fuel briquettes to address cooking energy demands while being sensitive to concurrent public health and climate change issues. For example,

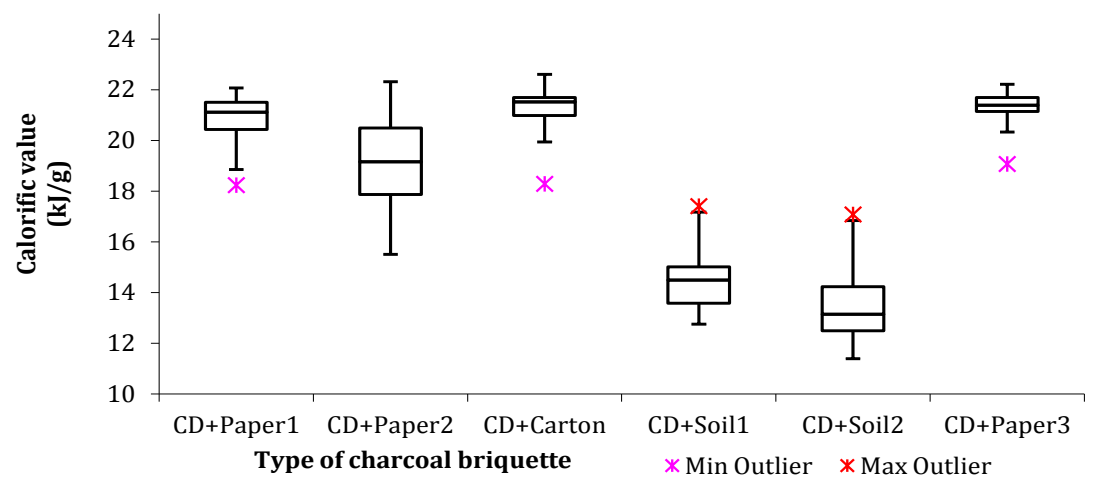

Fig. 4 Box plot on calorific value of briquettes produced by self-help groups 
Citation: Njenga, M., Yonemitsu, A., Karanja, N., liyama, M., Kithinji, J., Dubbeling, M., Sundberge, C. \& Jamnadass, R. (2013) Implications of Charcoal Briquette Produced by Local Communities on Livelihoods and Environment in Nairobi, Kenya. Int. Journal of Renewable Energy Development 2(1), 19-29

P a g e $\mid \mathbf{2 8}$

although charcoal briquette produces less smoke than charcoal, there is need to link its use to development of efficient cook stoves and public health education on indoor air pollution. Another area that requires financial support is awareness-raising on fuel briquettes as an alternative cooking fuel through numerous media, learning institutions and other social gatherings. For sustainable charcoal briquette production in the country there is need for adoption of more efficient wood carbonization processes as opposed to using the traditional methods with efficiency of $10-20 \%$ in yield currently being used by $99 \%$ of charcoal producers leading to immense wood wastage (Okello 2001; Mutimba \& Barasa 2005).

All households in informal settlements as found in the study at Kibera, use charcoal which fuel briquettes are substituting as the two types of cooking fuel use similar cook stoves. This substitution with charcoal briquettes contributes to saving trees, which is important as the country struggles to move from less than $2 \%$ of forest cover to the recommended $10 \%$. Saving trees has multiple benefits such as better management of water catchments, mitigating climate change as trees serve as carbon dioxide sinks, and conservation of biodiversity. Charcoal briquettes produce less emissions which is a positive indicator in addressing indoor air pollution which has been known to cause over 1.6 million annual deaths globally, 400,000 occurring in SSA (Ezzati et al. 2002). Promotion of charcoal briquette use should be combined with use of efficient cook stoves where for intance use of imporved Kenya Ceramic Jiko (KCJ) reduced emission of CO by 15\% (Kituyi 2001).

In juxtaposition, if charcoal dust is unrecovered, it poses a disposal problem and it is either dumped in open drains, polluting and clogging up the system, or burned, causing air pollution especially in the informal settlements in urban areas. Because charcoal dust is the main raw material for fuel briquette production in the country, the production process should be linked to research on and development of tree farming through short rotations for charcoal production. The charcoal briquette production should also be integrated in management of forests and tree resources through working with local communities as those in areas neighboring forests. Working with Community Forest Associations (CFAs) would be one way to reach these communities.

\section{Conclusions and recommendations}

Charcoal briquette production is a technology that helps poor urban dwellers, especially women and youth, with important employment and income opportunities. Charcoal briquettes provide affordable and good quality cooking energy for households in poor neighbourhoods. Technical capacity building in local communities through partnerships is necessary so as to improve on quality consistence. Charcoal dust briquettes have environmental benefits that include reduced tree degradation, better management of waste and reduced emissions. There is need to link charcoal briquette production to sustainable charcoal production such as short rotational agoforestry. Energy and waste management policy initiatives should include recovery of organic by-products for charcoal briquette production.

\section{Acknowledgement}

The various components of this research were supported by International Development Research Centre (IDRC), Japan International Centre for Agricultural Sciences (JIRCAS), World Agroforestry Centre (ICRAF), African Women in Agricultural Research and Development (AWARD) and the Borlaug LEAP.

\section{References}

Bailis, R., Ezzati, M. \& Kammen, D. (2005) Mortality and Greenhouse Gas Impacts of Biomass and Petroleum Energy Futures in Africa. Science, 308, 98-103.

Chidumayo, E.N., Masialeti, I., Ntalasha, H. \& Kalumiana, O.S. (2002) Charcoal Potential for Southern Africa. Zambia Final Report. University of Zambia/European Union. INCO-DEV 1998-2001.

Chou, C.S., Lin S.H. \& Lu W.C. (2009) Preparation and Characterization of Solid Biomass Fuel Made from Rice Straw and Rice Bran. Fuel Process Tech., 90, 980-987.

Ezzati, M., Lopez, A.D., Rodgers, A., Vander Hoorn, S. \& Murray, C.J. (2002) Comparative risk assessment collaborating group. Selected major risk factors and global and regional burden of disease. Lancet 2 (360),1347-1360.

Felfli, F., Juan, M., Mesa, P., Rocha, J., Filippetto, D., Luengo, C., Pippo, W. (2010) Biomass briquetting and its perspectives in Brazil. Biomass and Bioenergy, 1-7

Findlay, A. (1963) Practical Physical Chemistry, pp192. Longman Publishing.

Fuwape, J.A. (1993) Charcoal and Fuel Value of Agroforestry Tree Crops. Agroforestry Syst, 22, 175-179.

Gathui, T., Wairimu, N. (2010) Bioenergy and Poverty in Kenya: Attitudes, Actors and Activities. Working Paper. Practical Action Consulting.

Gitonga, S. (1997) Biogas Promotion in Kenya. A Review of Experiences. Practical Action, UK.

Gominho, J., Lourenco, A., Miranda, I. and Pereira, H. (2012) Chemical and Fuel Properties of Stumps Biomass from Eucalyptus globulus Plantations. Ind Crop and Prod. , 39, 12- 16

GTZ (2007) Eastern Africa Resource Base: GTZ Online Regional Energy Resource Base: Regional and Country Specific Energy Resource Database: II - Energy Resource.

Hecht, A.D., Shaw, D., Bruins, R., Dale, V., Kline, K. \& Chen, A. (2009) Good Policy Follows Good Science: Using Criteria and Indicators for Assessing Sustainable Biofuel Production. Ecotoxicol, 18, 1-4.

ITDG-EA (2003) 'Nairobi solid waste management network' [Online], Available by WasteNet http://www.wastenet.or.ke/ (posted 09.05.04; verified 11.02.04).

JICA (Japan International Cooperation Agency) (1997) Economic Infrastructure. Master plan study of Nairobi.

Karekezi, S. (2002) Renewables in Africa-Meeting The Energy Needs of The Poor, Energy Policy, 30, 1059-1069. 
Kituyi, E. (2004) Towards Sustainable Production and Use of Charcoal in Kenya: Exploring The Potential in Life Cycle Management Approach. J. Cleaner Production, 12, 1047-1057.

Kituyi, E., Marufu, L., Wandiga, S., Jumba, I., Andreae, M., Helas, G. (2001) Carbon Monoxide and Nitric Oxide from Biofuel Fires in Kenya, Energy Conversion and Management, 42(13), 1517-1542.

McBridea, A.C., Dalea, V.H., Baskarana, L.M., Downinga, M.E., Eatona, L.M., Efroymsona, R.A., Garten, C.T., Klinea, K.L., Jagera, H., Mulhollanda, P.J., Parisha, E.S., Schweizera, P.E., Storey, J.M (2011) Indicators to support environmental sustainability of bioenergy systems. Ecological Indicators 11, 1277-1289

Ministry of Energy, (MoE), Government of Kenya, (2002) Study on Kenya's energy demand, supply and policy strategy for households, small scale industries and service establishments, Final Report, May, KAMFOR Company Ltd., September.

Ministry of Energy, (MoE). Government of Kenya, (2009) Proposed National Biofuel Policy.

Ministry of Planning and National Development, Kenya (2003) Economic Survey.

Mugo, F., Nungo, R., Odongo, F., Chavangi, N., Abaru, M. (2007) An assessment of the energy saving potential and heat loss pattern in fireless cooking for selected commonly foods in Kenya. CARPA working paper series, No. 2.

Mutimba, S., and Barasa, M., (2005) National charcoal survey: Summary report. Exploring the potential for a sustainable charcoal industry in Kenya. Energy for Sustainable Development Africa (ESDA).

Nasrin, A.B., Ma A.N., Choo, Y.M., Mohamad, S., Rohaya, M.H., Azali, A., Zainal, Z. (2008) Oil palm biomass as potential substitution raw materials for commercial biomass briquettes production. Am. J. Appl. Sci., 5(3), 179-183.

Ngeregeza, F. (2003) Notes on a roundtable discussion on the status of the charcoal industry in Tanzania. Environmental Officer, VicePresident's Office, Division of Environment. Dar es Salaam, Tanzania.

Njenga M, Karanja N, Jamnadass R, Kithinji J, Sundberg, C, and Jirjis R (in press) Quality of Briquettes Produced Locally from Charcoal Dust and Sawdust in Kenya. J. Biobased Materials and Bioenergy.

Njenga, M., Romney, Karanja, N., Gathuru, K., Kimani, S., Carsan, S., Frost, W. (2010) Recycling nutrients from organic wastes in Kenya's capital city. In Prain, G., Karanja, N., Lee-Smith, D., eds. African urban harvest: Agriculture in the cities of Cameroon, Kenya and Uganda. IDRC CIP/Urban Harvest, 193-212.

Odoemenem IU, Obinne CPO (2010) Assessing the factors influencing the utilization of improved cereal crop production technologies by small-scale farmers in Nigeria. Indian J Science and Technol 3 (1), 180-183.

Okello, B.D., O'Connor, T.G., Young, T.P. (2001) Growth, biomass estimates, and charcoal production of Acacia drepanolobium in Laikipia, Kenya. Forest Ecol. and Manag., 142, 143-153

Ölz, S., Sims, R., Kirchne, N. (2007) Contribution of renewables to energy security. International Energy Agency.

Rousseta, P., Caldeira-Piresb, A., Sablowskic, A., Thiago Rodriguesd, T. (2011) LCA of eucalyptus wood charcoal briquettes. J Cleaner Production, 19(14), 1647-1653

Shepherd, K., Walsh, M. (2007) Infrared spectroscopy-enabling an evidence-based diagnostic surveillance approach to agricultural and environmental management in developing countries. J. Near Infrared Spec., 15, 1-19.

Sotannde OA, Oluyege AO, Abah GB (2010a) Physical and combustion properties of charcoal briquettes from neem wood residues. Int. Agrophysics. 24: 189-194.

Sotannde, O.A., Oluyege, A.O., Abah, G.B. (2010b) Physical and combustion properties of briquet from sawdust of Azadirachtaindica. J Forestry Research 21(1), 63-67.

Suarez, J.A., Luengo, C.A., Fonseca, F.F., Bezzon, G., Beaton, P.A. (2000) Thermochemical properties of Cuban biomass. Energ Sources. 22, 851-867.

Nuova, T., \& AMREF-Kenya (2007) Briquette technology. An informative research report on briquette making technology in Kenya

UNEP Year Book (2011) Emerging issues in our global environment. United Nations Environment Programme, Nairobi.

UN-HABITAT (2010) State of the World's Cities 2010/2011 - Cities for All: Bridging the Urban Divide. EARTHSCAN, London and Washington DC.

UN-Habitat (2006) Nairobi urban sector profile. UN-Habitat Nairobi.

Van Loo, S., Koppejan, J. eds (2009) The handbook of biomass combustion and co-firing. Earthscan UK and USA.

Wamukonya L, Jenkins B (1995) Durability and relaxation of sawdust and wheat-straw briquettes as possible fuels for Kenya. Biomass and Bioenergy 8: 175-179

Wilaipon, P. (2007) Physical characteristics of maize cob briquette under moderate die pressure. Am. J. App. Sci., 4, 995-998.

Yigard, M.M. (2002) Woodfuel policy and legislation in Ethiopia: In: Mugo, F., Ong, C., 2006. Lessons of Eastern Africa's unsustainable charcoal trade. ICRAF Working Paper no. 20. Nairobi, Kenya. World Agroforestry Centre. 